\title{
Population status of the Bornean orang-utan Pongo pygmaeus in a vanishing forest in Indonesia: the former Mega Rice Project
}

\author{
Megan E. Cattau, Simon Husson and Susan M. Cheyne
}

\begin{abstract}
As peat-swamp forests in Borneo become progressively more fragmented, the species that inhabit them are increasingly threatened, notably the Endangered Bornean orang-utan Pongo pygmaeus. The area of a failed agricultural project known as the Mega Rice Project in Central Kalimantan, Indonesia, is composed of fragments of peat-swamp forest that are reported to contain orang-utans, although no comprehensive survey has previously been conducted. In a portion of this area we identified remaining forest fragments, using satellite imagery, and surveyed line transects for orang-utan sleeping nests to determine the density, abundance and distribution of the species. The total area of peat-swamp forest in the study area is $76,755 \mathrm{ha}$, 59,948 ha of which comprises patches at least as large as the home range of a female orang-utan ( $250 \mathrm{ha})$. We estimate a mean population density of $2.48 \pm \mathrm{SE} 0.32$ individuals $\mathrm{km}^{-2}$ and a population of $1,700 \pm$ SE 220 or $1,507 \pm$ SE 195 individuals, based on a 25 and 250 ha minimum patch size threshold, respectively. This is c. $40-45 \%$ of the original population, and the fragmented population is unlikely to be viable in terms of long-term demographic and genetic stability. To ensure persistence of this population of orangutans, direct conservation action to connect forest fragments and prevent further loss of peat-swamp forest will be required, including re-establishing the hydrological regime, reforesting barren areas and fighting fires.
\end{abstract}

Keywords Borneo, distance sampling, Endangered species, orang-utan, peat-swamp forest, Pongo pygmaeus, population status, remote sensing

MEgan E. CATTAU ${ }^{*} \dagger$ (Corresponding author) Nicholas School of the Environment, Duke University, 450 Research Drive, Durham, NC 27708, USA. E-mail mec2201@columbia.edu

Simon Husson and Susan M. Cheyne $\neq$ Orangutan Tropical Peatland Project, Center for International Cooperation in the Sustainable Management of Tropical Peatlands, University of Palangka Raya, Central Kalimantan, Indonesia

*Current address: Department of Ecology, Evolution, and Environmental Biology, Columbia University, 1200 Amsterdam Avenue, New York, NY 10027, USA

$\dagger$ Also at: Orangutan Tropical Peatland Project, Center for International Cooperation in the Sustainable Management of Tropical Peatlands, University of Palangka Raya, Central Kalimantan, Indonesia

\$Also at: Wildlife Conservation Research Unit, Department of Zoology, University of Oxford, Abingdon, UK

Received 4 January 2013. Revision requested 11 March 2013.

Accepted 15 July 2013. First published online 27 August 2014.

\section{Introduction}

$\mathrm{T}$ their natural condition, lowland peat-swamp forests in South-east Asia provide invaluable ecosystem services at local and global scales. They prevent flooding, resist largescale fires and sequester and store carbon (Page \& Rieley, 1998; Page et al., 2002, 2006; Hooijer et al., 2006; Yule, 2010). They are also rich in endemic, rare and threatened flora and fauna ( $\mathrm{Ng}$ et al., 1994; Yule, 2010). However, peatland areas all over South-east Asia, including in Kalimantan, Indonesia, are being degraded and fragmented, in part as a result of the development of oil palm plantations, other forms of agriculture, logging and the secondary effects of these disturbances, including drainage, peat subsidence and fire (Barr, 2002; Hooijer et al., 2006; Koh et al., 2011). By 2006 c. $45 \%$ of South-east Asia's 27 million ha of peat forest had been deforested (Hooijer et al., 2006) and projections of deforestation under a business-as-usual scenario indicate that just under half of the peat-swamp forest in Central Kalimantan may be lost by 2020 (Fuller et al., 2011).

As the forests of South-east Asia become more sparse, species that depend on these areas for habitat or breeding are increasingly threatened (Sodhi et al., 2004). Of particular note is the Bornean orang-utan Pongo pygmaeus, because some of the highest densities of this species are found in lowland peat-swamp forest (Husson et al., 2009). The Bornean orang-utan is categorized as Endangered on the IUCN Red List (Ancrenaz et al., 2008), with a decreasing population trend attributed primarily to forest loss (Singleton et al., 2004; Ancrenaz et al., 2008). Some researchers predict that the extinction of the orang-utan is imminent if current trends of forest loss continue (Rijksen \& Meijaard, 1999; Williams, 2007; but see Meijaard \& Wich, 2007).

Effective conservation efforts for these great apes will require accurate baseline information on their density and distribution. This information will be particularly important in unprotected areas, which are home to the majority of orang-utans (Singleton et al., 2004; Wich et al., 2012) and which remain vulnerable to conversion for commercial purposes. We present the first spatially explicit, landscapescale analysis that aims to describe the status of the population of southern Bornean orang-utans $P$. pygmaeus wurmbii that inhabit an unprotected area known as Block C of the former Mega Rice Project, Central Kalimantan, Indonesia. Specifically, our objectives are (1) to identify the remaining forest patches in Block $\mathrm{C}$ that contain 


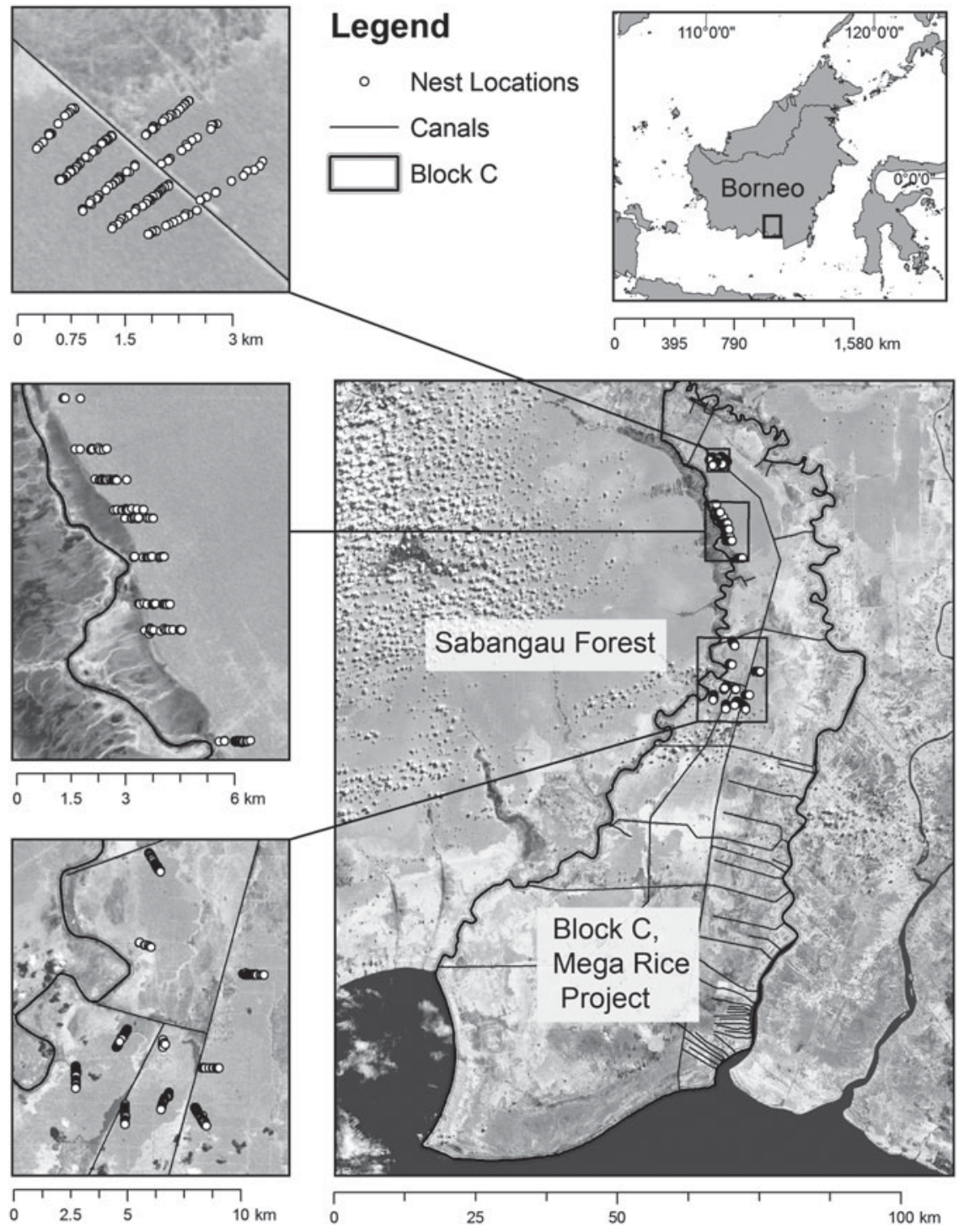

FIG. 1 Block C of the former Mega Rice Project in Central Kalimantan, Indonesia, including locations of orangutan Pongo pygmaeus nests along survey transects. orang-utans and quantify the total area of habitat remaining, and (2) to estimate the density and size of viable populations of orang-utans in these patches.

\section{Study area}

The Mega Rice Project in Central Kalimantan, Indonesia, is a failed agricultural project that was initiated in 1995 (Presidential Decree RI/82-26, 1995). Over 1 million ha of lowland peat-swamp forest, of a total of 6.8 million ha in Kalimantan, were targeted for conversion into rice paddies (Boehm \& Siegert, 1999; Sabiham, 2004). Drainage and irrigation canals were constructed and forest was cleared. However, the project was abandoned because the soil proved to be too acidic for rice cultivation and the canals had drained the peat (Aldhous, 2004).

Our study area is Block C of the Mega Rice Project, which comprises five blocks in total (Fig. 1). Drainage canals were built throughout Block $\mathrm{C}$ but the forest was never cleared.
Nevertheless, nearly $70 \%$ of the original peat-swamp forest in Block C had been lost as of 2000 (Boehm \& Siegert, 2001), primarily as a result of fires caused by a combination of drought and drainage by canals during 1997-1998. Further forest loss was recorded during the dry seasons of 2002, 2004, 2006 and 2009. Block C remains designated for conversion to agriculture, and oil palm development has begun in the far south although the majority of Block $\mathrm{C}$ is protected under a temporary moratorium on logging and conversion. All of the fragmented forest patches in Block $\mathrm{C}$ are reported to contain orang-utans, but prior to this study no comprehensive census of the area had been conducted.

\section{Methods}

Land cover analysis and habitat identification

A land cover assessment of the study area was conducted using satellite data (Landsat 7 ETM+ data acquired 19 May 
2008, the closest date prior to the study period for which relatively cloud-free data are available). The data were radiometrically and atmospherically corrected and we completed a supervised classification, using a maximumlikelihood decision rule, to categorize the data for Block $\mathrm{C}$ into the following land cover/land use categories: mature forest, degraded or secondary forest, grassland/shrubland, sparsely vegetated, barren or recently burned, cloud, cloud shadow, and water/inundated. Training sites for spectral signatures were based on our on-the-ground knowledge of the study area and global positioning system points that we collected in the field for each land cover/land use category (i.e. ground-truthing points). Focal statistics were used to reassign values to the pixels with no data or classified as cloud and cloud shadow. Although agricultural areas were difficult to distinguish from other categories because of their high spectral variability, the visible fine-scale irrigation canals running throughout made it possible to hand-digitize the agricultural areas. We used an error matrix to conduct an accuracy assessment using the ground-truthing points that were withheld from model development. Overall classification accuracy was $>85 \%$. Irrigation canals (referenced shapefiles provided by Agata Hoscilo of Leicester University, UK) were incorporated into this classified image using ArcGIS v. 9.3 (ESRI, Redlands, USA). We distinguished peat-swamp forest from other forest, including freshwater swamp, mangrove and heath forests, based on our on-the-ground knowledge and ground-truthing points. To identify patches of suitable orang-utan habitat, we retained only the mature and secondary or degraded peatswamp forest classes and excluded patches $<25 \mathrm{ha}$, which are unlikely to provide habitat for orang-utans. We chose a 250 ha minimum patch size threshold, at the lower end of the best estimate of minimum home range size of female P. pygmaeus wurmbii in Sabangau (Singleton et al., 2009), to quantify remaining habitat that is likely to support orangutans in the long term. Although it is possible that forest fragments $<250$ ha contain resident orang-utans, fragments are isolated by burnt and deforested land, thus impeding movement between fragments and reducing the long-term viability of these fragments for orang-utans.

\section{Density and population size estimation}

Line-transect distance sampling (Buckland et al., 1993, 2001) for sleeping nests, a standard method for calculating ape abundance (Kuhl et al., 2008), was conducted during June-July 2009 as part of a multi-disciplinary research project run jointly by the Orangutan Tropical Peatland Project and the Center for International Cooperation in the Sustainable Management of Tropical Peatlands. Line transects were hand-cut systematically, with random starting points, through all accessible forested patches in
Block C (Fig. 1). We did not survey patches that were physically inaccessible or that the property owner did not give us permission to access. A total of 27 transects (with a total length of $26.3 \mathrm{~km}$ ) were surveyed. Observers walked slowly along the transects, looking in all directions for orang-utan sleeping nests. For each nest sighted, the distance along the transect and the perpendicular distance from the nest to the transect were measured.

We used DISTANCE v. 6.o (Thomas et al., 1998, 2010) to estimate orang-utan nest density. The software fits several possible robust, semi-parametric models to the data to determine the probability of detection as a function of the distance of the observed nest from the transect, or the effective strip width. The effective strip width was estimated regionally (across Block $\mathrm{C}$ ). We selected a half-normal + cosine model key function/series expansion based on the lowest Akaike Information Criterion (AIC $=4,038.73$ ). We divided the data into 10 equal intervals to smooth the histogram and improve the model (AIC $=2,620.34$; probability of a greater $\chi^{2}$ goodness-of-fit value, $\mathrm{P}=0.19$ ). Nest density was estimated locally (per patch) using the formula $d_{n}=N / L \times 2 w$, where $d_{n}$ is nest density (nests per $\mathrm{km}^{2}$ ), $N$ is the number of observed nests per patch, taking into account a $30 \mathrm{~m}$ truncation, $L$ is the sum of the lengths of the transects (in $\mathrm{km}$ ) per patch, and $w$ is the effective strip width (in $\mathrm{km}$ ); variance was derived using analytical estimates. We assigned the regional nest density estimate to the patches that were not surveyed.

To estimate population density we used the formula of van Schaik et al. (1995): $d_{\mathrm{o}}=d_{n} /\left(p^{*} r^{*} t\right)$, where $d_{\mathrm{o}}$ is orangutan density (individuals per $\mathrm{km}^{2}$ ), $d_{n}$ is nest density, $p$ is the proportion of nest-builders in the population, $r$ is the rate at which nests are produced (nests per day per individual) and $t$ is the decay rate of nests, or time during which a nest remains viable (days). Accurate values of $p, r$ and $t$ are vital for producing accurate density estimates (Marshall \& Meijaard, 2009) and these values, particularly $t$, can vary considerably between field sites (van Schaik et al., 1995, 2005; Morrogh-Bernard et al., 2003; Mathewson et al., 2008). We used parameter values derived from the adjacent Sabangau Forest ( $p=0.89, r=1.17, t=365.16 \pm \mathrm{SE} 8.76$; Husson et al., 2009), which is geographically close to, recently contiguous with, and ecologically similar to the Mega Rice Project area. We also included density estimates calculated using the full range of values reported for the parameters $p, r$ and $t$ in peat-swamp forests in Borneo (Table 3 ).

We estimated orang-utan numbers for each forest patch by extrapolating density estimates and the associated standard error to patch sizes derived from the satellite data. We applied a correction factor of 1.475, as suggested in Husson et al. (2009), to produce a standardized density estimate, which can be compared with standardized density estimates of other populations, calculated based on different survey methods. This correction factor accounts for depressed 
(a)

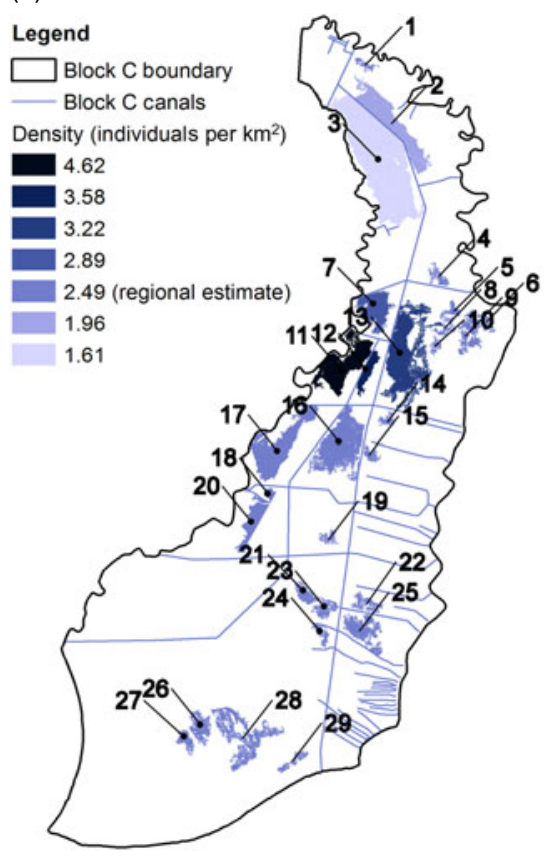

(b)

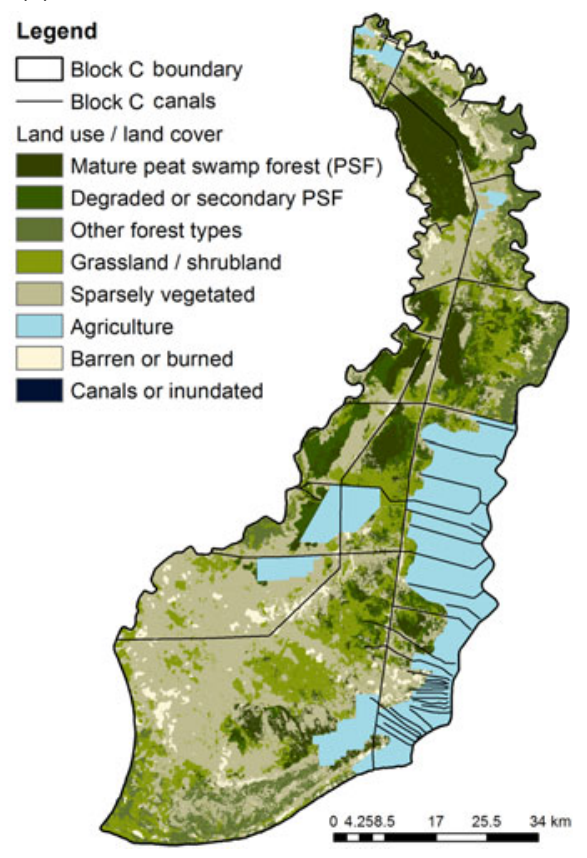

FIG. 2 (a) Land cover/land use in Block $\mathrm{C}$ of the former Mega Rice Project in Central Kalimantan, Indonesia. (b) Habitat patches of $>250$ hectares and estimated orang-utan population density within Block C. estimates of nest density based on a survey design in which line transects are surveyed only once, compared with line transects with a repeat survey technique or plots. To avoid overestimation we used our original uncorrected density estimates to calculate orang-utan numbers for each patch and extrapolate a minimum population estimate.

\section{Results}

According to the land cover/land use classification (Fig. 2), c. $10 \%$ of the area in Block $\mathrm{C}$ comprises peat-swamp forest (Table 1). This increases to $17 \%$ when degraded or secondary peat-swamp forest is included, which represents an area of 76,755 ha (Table 1), 67,718 ha of which comprises patches $>25$ ha. The area of viable habitat (fragments $>250 \mathrm{ha}$ ) is 59,948 ha, distributed among 29 patches (Table 2).

The DISTANCE analysis indicates an effective strip width of $13.09 \mathrm{~m}$ for the survey, and a nest density estimate of $944.77 \pm$ SE $103.07 \mathrm{~km}^{-2}$. Orang-utan density estimates based on the range of published values for the parameters $p, r$ and $t$ in peat-swamp forests in Borneo vary from $2.27 \pm$ SE 0.25 to $2.56 \pm$ SE $0.28 \mathrm{~km}^{-2}$ (Table 3). Using the values for $p, r$ and $t$ from Sabangau, the density estimate for Block $\mathrm{C}$ is $2.48 \pm \mathrm{SE} 0.32$ individuals $\mathrm{km}^{-2}$ and the standardized density estimate is $3.66 \pm \pm \mathrm{SE} 0.47 \mathrm{~km}^{-2}$. The density of orang-utans in the patches that were surveyed directly ranges from $1.61 \pm \mathrm{SE} 0.21$ to $4.62 \pm \mathrm{SE} 0.60 \mathrm{~km}^{-2}$ (Fig. 2, Table 2). Based on patch-specific density estimates for the patches that were surveyed and the regional density estimate for the patches that were not, the population size over the entire Block $C$ is $1,507 \pm \mathrm{SE} 195$ to $1,700 \pm \mathrm{SE} 220$
TABle 1 Land use/land cover in Block C of the Mega Rice Project, Central Kalimantan, Indonesia (Fig. 1), with land area and percentage of landscape.

\begin{tabular}{lcc}
\hline Land use/land cover & $\begin{array}{l}\text { Area } \\
\text { (ha) }\end{array}$ & $\begin{array}{l}\text { \% of } \\
\text { landscape }\end{array}$ \\
\hline Mature peat-swamp forest & 46,557 & 10.4 \\
Degraded or secondary peat-swamp forest & 30,198 & 6.7 \\
Other forest types & 29,823 & 6.6 \\
Grassland/shrubland & 76,489 & 17.0 \\
Sparsely vegetated & 163,665 & 36.5 \\
Agriculture & 78,267 & 17.4 \\
Barren or burned & 20,453 & 4.6 \\
Canals or inundated & 3,471 & 0.8 \\
\hline
\end{tabular}

(Table 2), using 250 and 25 ha minimum patch size thresholds, respectively. It is thought that 250 individuals are a genetically viable population over the long term (Singleton et al., 2004), and none of the forest fragments support such a population, with the potential exception of patches 3 and 13, with $227 \pm$ SE 29 and $232 \pm$ SE 30 individuals, respectively (Table 2). However, none of these populations should be abandoned, as the larger landscape supports a large population, which highlights the importance of developing a management plan that incorporates orang-utan habitat connectivity in Block C.

\section{Discussion}

We identified the density and abundance of Bornean orangutan subpopulations and quantified the remaining habitat area in Block $\mathrm{C}$ of the former Mega Rice Project to 
TABle 2 Patch area, mean orang-utan Pongo pygmaeus wurmbii density, and mean number of orang-utans in each patch $>250$ ha in Block C of the Mega Rice Project, Central Kalimantan, Indonesia (Fig. 1). The regional density estimate (Block C-wide) is applied to the patches that were not surveyed directly.

\begin{tabular}{|c|c|c|c|}
\hline Patch & $\begin{array}{l}\text { Area } \\
\text { (ha) }\end{array}$ & $\begin{array}{l}\text { Mean density } \pm \\
\text { SE }\left(\mathrm{km}^{-2}\right)\end{array}$ & $\begin{array}{l}\text { Mean number of } \\
\text { individuals } \pm \text { SE }\end{array}$ \\
\hline 1 & 276 & $2.48 \pm 0.32$ & $7 \pm 1$ \\
\hline 2 & 4,394 & $1.96 \pm 0.25$ & $86 \pm 11$ \\
\hline 3 & 14,117 & $1.61 \pm 0.21$ & $227 \pm 29$ \\
\hline 4 & 488 & $2.48 \pm 0.32$ & $12 \pm 2$ \\
\hline 5 & 362 & $2.48 \pm 0.32$ & $9 \pm 1$ \\
\hline 6 & 317 & $2.48 \pm 0.32$ & $8 \pm 1$ \\
\hline 7 & 2,392 & $2.89 \pm 0.32$ & $69 \pm 9$ \\
\hline 8 & 408 & $2.48 \pm 0.32$ & $10 \pm 1$ \\
\hline 9 & 1,370 & $2.48 \pm 0.32$ & $34 \pm 4$ \\
\hline 10 & 263 & $2.48 \pm 0.32$ & $7 \pm 1$ \\
\hline 11 & 4,296 & $4.62 \pm 0.60$ & $199 \pm 26$ \\
\hline 12 & 978 & $3.57 \pm 0.46$ & $35 \pm 5$ \\
\hline 13 & 7,213 & $3.21 \pm 0.41$ & $232 \pm 30$ \\
\hline 14 & 320 & $2.48 \pm 0.32$ & $8 \pm 1$ \\
\hline 15 & 377 & $2.48 \pm 0.32$ & $9 \pm 1$ \\
\hline 16 & 5,419 & $2.48 \pm 0.32$ & $135 \pm 17$ \\
\hline 17 & 4,701 & $2.48 \pm 0.32$ & $117 \pm 15$ \\
\hline 18 & 400 & $2.48 \pm 0.32$ & $10 \pm 1$ \\
\hline 19 & 361 & $2.48 \pm 0.32$ & $9 \pm 1$ \\
\hline 20 & 1,546 & $2.48 \pm 0.32$ & $38 \pm 5$ \\
\hline 21 & 698 & $2.48 \pm 0.32$ & $17 \pm 2$ \\
\hline 22 & 693 & $2.48 \pm 0.32$ & $17 \pm 2$ \\
\hline 23 & 687 & $2.48 \pm 0.32$ & $17 \pm 2$ \\
\hline 24 & 405 & $2.48 \pm 0.32$ & $10 \pm 1$ \\
\hline 25 & 1,924 & $2.48 \pm 0.32$ & $48 \pm 6$ \\
\hline 26 & 1,136 & $2.48 \pm 0.32$ & $28 \pm 4$ \\
\hline 27 & 577 & $2.48 \pm 0.32$ & $14 \pm 2$ \\
\hline 28 & 3,375 & $2.48 \pm 0.32$ & $84 \pm 11$ \\
\hline 29 & 455 & $2.48 \pm 0.32$ & $11 \pm 1$ \\
\hline Total & 59,948 & & $1,507 \pm 195$ \\
\hline
\end{tabular}

contribute to a more focused conservation effort for this population of c. 1,500-1,700 orang-utans.

Prior to the construction of irrigation canals in 1995-1996, Block C contained 233,275 ha of peat-swamp forest (Boehm \& Siegert, 2001). Since then, c. $70 \%$ of the forest has been lost as a result of rapid forest fragmentation and subsequent drainage and fire, and the orang-utans have become confined to habitat fragments. The current population density may be temporarily inflated above the carrying capacity of the fragments, and therefore the population may be unable to persist in the long term because of this extinction debt (Tilman et al., 1994), as may also be the case in other areas that have experienced rapid loss of peat forest in recent history. Supporting this, our standardized density estimate of $3.66 \pm$ SE 0.47 individuals $\mathrm{km}^{-2}$ for this site is relatively high compared to the adjacent Sabangau area, with a standardized density estimate of 1.12-2.49 individuals $\mathrm{km}^{-2}$ (Husson et al., 2009).
Using a density estimate derived from an intact mixed swamp forest area adjacent to the Mega Rice Project (nest density estimate $599 \pm$ SE $78 \mathrm{~km}^{-2}$; Morrogh-Bernard et al., 2003) as a pre-canal baseline, we estimate the original population in Block $\mathrm{C}$ to have been $3,676 \pm \mathrm{SE} 479$ orang-utans, c. $55-60 \%$ of which have been lost. Unless the area of viable habitat increases, the population density will probably decrease further. If it decreases to 1.58 individuals $\mathrm{km}^{-2}$ (derived from an adjacent intact mixed swamp forest area; Morrogh-Bernard et al., 2003) the population on Block C would be reduced to $945 \pm$ SE 123 (minimum patch size $250 \mathrm{ha}$ ) to $1,067 \pm \mathrm{SE} 139$ (minimum patch size $25 \mathrm{ha}$ ) individuals, assuming no further loss of forest were to occur. This underscores the need to reforest barren areas and to connect existing forest fragments.

The effective conservation of this population will also require information concerning how orang-utan population ecology is affected by changes in habitat extent and spatial configuration. Although the effects of forest disturbance (e.g. logging) on orang-utan density and demography (Felton et al., 2003; Morrogh-Bernard et al., 2003) and behaviour (Hardus et al., 2012) have been documented, little is known about how orang-utans respond to a harsh nonforest matrix (e.g. barren or grassland areas) and how they use these non-forest areas, if at all. It is expected that they rarely disperse between forest fragments (van Schaik et al., 2001). This may not be the case in a multi-functional landscape, such as plantation matrix (Meijaard et al., 2010) or mixed agroforestry systems (Campbell-Smith et al., 2011a,b), but is probably the case in places such as the Mega Rice Project where the matrix is relatively harsh. However, if orang-utans traverse the matrix relatively frequently it is thought that small forest patches supplement the habitat area provided by larger patches. If we categorized all peatswamp forest areas as habitat, the population estimate for Block C would increase to $1,925 \pm$ SE 249 .

We selected a 250 ha threshold for the minimum habitat patch size, based on the range requirements of female orang-utans (Singleton et al., 2009). However, male home ranges are larger (Galdikas, 1988; Nietlisbach et al., 2012) and they are not exclusive or stable (van Schaik \& van Hooff, 1996). Thus, the spatial distribution of habitat patches is especially important for dispersal of male orang-utans and the resulting genetic variation in individuals and connectivity between meta-populations across the landscape. More research on the movement patterns of orang-utans in a fragmented landscape is required (see Goossens et al., 2005, for the genetic effects of fragmentation).

The importance of this population to the persistence of the species regionally and globally is an issue of value judgement and prioritization. The population has limited potential to connect to other populations of orang-utans, as it became functionally isolated from populations in the Sabangau Forest with the development of the city of 
TABLE 3 Orang-utan density estimates for Block C, based on the range of published values for the parameters $p, r$ and $t$ for peat-swamp forests in Borneo and the standard error associated with nest density in our dataset (but not our parameter estimates). The best estimates for parameter values for Block C of the Mega Rice Project yield an estimated density of $2.48 \pm$ SE 0.27 individuals per km².

\begin{tabular}{lllll}
\hline$p$ & $r\left(t=365^{1,2}\right)$ & & $r\left(t=399^{3}\right)$ \\
\hline & $1.15^{4}$ & $1.17^{1,5}$ & $1.15^{4}$ & $1.17^{5}$ \\
$0.88^{4}$ & $2.56 \pm$ SE 0.28 & $2.51 \pm$ SE 0.27 & $2.34 \pm$ SE 0.26 & $2.30 \pm$ SE 0.25 \\
$0.89^{1,5}$ & $2.53 \pm$ SE 0.28 & $2.48 \pm$ SE 0.27 & $2.31 \pm$ SE 0.25 & $2.27 \pm$ SE 0.25 \\
\hline
\end{tabular}

${ }^{1}$ Best estimates for parameter values for Block C of the Mega Rice Project

${ }^{2}$ Husson (unpubl. data)

${ }^{3}$ Johnson et al. (2005)

${ }^{4}$ van Schaik et al. (2005)

${ }^{5}$ Morrogh-Bernard (unpubl. data)

Palangka Raya. In terms of numbers this population accounts for c. $2-4 \%$ of the global total and $4-5 \%$ of the subspecies P. pygmaeus wurmbii (Wich et al., 2008). However, every viable population contributes to the persistence of the species, and the Indonesian government has made a commitment to stabilize all populations of orang-utans and their habitat (Soehartono et al., 2007). Furthermore, this population is potentially the seventh largest population of P. pygmaeus wurmbii (Wich et al., 2008). For this population to persist, direct conservation action in the area will be required, including closing the irrigation canals, reforesting barren areas and fighting fires. Although efforts are being made to restore Block $\mathrm{C}$, they are small-scale, limited and underfunded and this scenario is likely to continue if land is designated for conversion and not conservation.

The loss of peat-swamp forest could potentially be slowed by climate mitigation policies that provide financial incentives for avoiding carbon emissions. Peatlands have a large capacity for below-ground carbon sequestration and storage and, thus, an effect on global carbon cycles and climate change (Sorensen, 1993). The Oslo Pact (Solheim \& Natalegawa, 2010) was initiated in 2011, with a 2-year moratorium on new permits for the conversion or logging of carbon-rich deep peatlands $(>50 \mathrm{~cm})$ and of primary forest (Presidential Instruction No. 10/2011). It was extended for an additional 2 years (Presidential Instruction No. 6/2013), which could benefit peat-swamp conservation, particularly in Block $\mathrm{C}$, the majority of which is protected under the moratorium. If the moratorium is properly enforced and continually renewed, it could have a significant effect on the area's capacity to support orang-utans in the long term. To evaluate the agreement's contribution to orang-utan conservation at the national scale it will be critical to determine to what extent the areas protected under the agreement overlap with orang-utan habitat.

In addition to supporting the moratorium we also recommend conserving the marginal, shallower peat zones that fall outside the protection of the moratorium. Management of these shallow areas is required to maintain water tables in the upslope, deep interior peat areas, and these are some of the areas in which orang-utan densities are highest. The highest priorities are to prevent further oxidation of peatlands, increase the quantity and connectivity of the forest for the resident population of orang-utans and decrease the likelihood of the detrimental peatland fires that have been occurring in this region since the 1990 .

\section{Acknowledgements}

We thank the Kuzmier-Lee-Nikitine Endowment Fund, the SIDG-Lazar Foundation, the Nicholas School International Internship Fund and the Orangutan Foundation for financial support for this project; Hendri and Ari Purwanto for research support; and Dean Urban and Jennifer Swenson of Duke University and two anonymous reviewers for helpful comments on this article. The Orangutan Tropical Peatland Project works in partnership with the Center for International Cooperation in Sustainable Management of Tropical Peatland and would like to thank the University of Palangka Raya for ongoing support, the Ministry of Research and Technology for permission to undertake research in Indonesia, and the Wallace Global Fund, the Arcus Foundation, the Australian Orangutan Project, Rufford Small Grants for Nature and the U.S. Fish \& Wildlife Service Great Apes Conservation Fund for financial support.

\section{References}

Aldhous, P. (2004) Land remediation: Borneo is burning. Nature, 432, 144-146.

Ancrenaz, M., Marshall, A., Goossens, B., van Schaik, C., Sugardjito, J., Gumal, M. \& Wich, S. (2008) Pongo pygmaeus. In IUCN Red List of Threatened Species v. 2010.1. Http://www. iucnredlist.org [accessed 20 December 2012].

BARR, C. (2002) Timber concession reform: questioning the "sustainable logging' paradigm. In Which Way Forward? People, Forests, and Policymaking in Indonesia (eds C.J.P. Colfer \& I.A.P. Resosudarmo), pp. 191-220. Resources for the Future, Center for International Forestry Research (CIFOR) and Institute of Southeast Asian Studies (ISEAS), Washington, DC, USA. 
Boenm, H.D.V. \& Siegert, F. (1999) Application of remote sensing and GIS to survey and evaluate tropical peat. In The International Conference and Workshop on Tropical Peat Swamps: Safe-guarding a Global Natural Resource, pp. 341-356. Kalteng Consultants, Penang, Malaysia.

Boenm, H.D.V. \& Siegert, F. (2001) Ecological impact of the one million hectare rice project in Central Kalimantan, Indonesia, using remote sensing and GIS. In 22nd Asian Conference on Remote Sensing, 5-9 November 2001, Singapore, pp. 1-6. Centre for Remote Imaging, Sensing and Processing CRISP, National University of Singapore, Singapore Institute of Surveyors and Values SISV and Asian Association on Remote Sensing.

Buckland, S.T., Anderson, D.R., Burnham, K.P. \& Laake, J.L. (1993) Distance Sampling: Estimating Abundance of Biological Populations. Chapman \& Hall, London, UK.

Buckland, S.T., Anderson, D.R., Burnham, K.P., Laake, J.L., Borchers, D.L. \& Thomas, L. (2001) Introduction to Distance Sampling: Estimating Abundance of Biological Populations. Oxford University Press, New York, USA.

Campbell-Smith, G., Campbell-Smith, M., Singleton, I. \& Linkie, M. (2011a) Apes in space: saving an imperilled orangutan population in Sumatra. PLoS ONE, 6(2), e17210.

Campbell-Smith, G., Campbell-Smith, M., Singleton, I. \& Linkie, M. (2011b) Raiders of the lost bark: orangutan foraging strategies in a degraded landscape. PLoS ONE, 6(6), e20962.

Felton, A.M., Engström, L.M., Felton, A. \& Knott, C.D. (2003) Orangutan population density, forest structure and fruit availability in hand-logged and unlogged peat swamp forests in West Kalimantan, Indonesia. Biological Conservation, 114, 91-101.

Fuller, D.O., Hardiono, M. \& Meijaard, E. (2011) Deforestation projections for carbon-rich peat swamp forests of Central Kalimantan, Indonesia. Environmental Management, 48, 436-447. Galdikas, B.M.F. (1988) Orangutan diet, range, and activity at Tanjung Puting, Central Borneo. International Journal of Primatology, 9, 1-35.

Goossens, B., Chikhi, L., Jalil, M.F., Ancrenaz, M., Lackman-Ancrenaz, I., Mohamed, M. et al. (2005) Patterns of genetic diversity and migration in increasingly fragmented and declining orang-utan (Pongo pygmaeus) populations from Sabah, Malaysia. Molecular Ecology, 14, 441-456.

Hardus, M.E., Lameira, A.R., Menken, S.B.J. \& Wich, S.A. (2012) Effects of logging on orangutan behavior. Biological Conservation, $146,177-187$

Hooijer, A., Silvius, M., Wösten, H. \& Page, S. (2006) PEAT-CO2, Assessment of $\mathrm{CO}_{2}$ emissions from drained peatlands in SE Asia. Delft Hydraulics report Q3943.

Husson, S.J., Wich., S.A., Marshall, A.J., Dennis, R.D., Ancrenaz, M., Brassey, R. et al. (2009) Orangutan distribution, density, abundance and impacts of disturbance. In Orangutans: Geographic Variation in Behavioral Ecology and Conservation (eds S.A. Wich, S.S. Utami Atmoko, T. Mitra Setia \& C.P. van Schaik), pp. 77-96. Oxford University Press, Oxford, UK.

Johnson, A.E., Knott, C.D., Pamungkas, B., Pasaribu, M. \& Marshall, A.J. (2005) A survey of the orangutan (Pongo pygmaeus wurmbii) population in and around Gunung Palung National Park, West Kalimantan, Indonesia based on nest counts. Biological Conservation, 121, 495-507.

Koh, L.P., Miettinen, J., Liew, S.C. \& Ghazoul, J. (2011) Remotely sensed evidence of tropical peatland conversion to oil palm. Proceedings of the National Academy of Sciences of the United States of America, 108, 5127-5132.

Kuhl, H., Maisels, F., Ancrenaz, M. \& Williamson, E.A. (2008) Best Practice Guidelines for Surveys and Monitoring of Great Ape
Populations. IUCN SSC Primate Specialist Group, Gland, Switzerland.

Marshall, A.J. \& Meijaard, E. (2009) Orang-utan nest surveys: the devil is in the details. Oryx, 43, 416-418.

Mathewson, P.D., Spehar, S.N., Meijaard, E., Nardiyono, Purnomo, Sasmirul, A. et al. (2008) Evaluating orangutan census techniques using nest decay rates: implications for population estimates. Ecological Applications, 18, 208-221.

Meijaard, E., Albar, G., Nardiyono, Rayadin, Y., Ancrenaz, M. \& SPEHAR, S. (2010) Unexpected ecological resilience in Bornean orangutans and implications for pulp and paper plantation management. PLoS ONE, 5(9), e12813.

Meijaard, E. \& Wich, S. (2007) Putting orang-utan population trends into perspective. Current Biology, 17, R540.

Morrogh-Bernard, H., Husson, S., Page, S.E. \& Rieley, J.O. (2003) Population status of the Bornean orang-utan (Pongo pygmaeus) in the Sebangau peat swamp forest, Central Kalimantan, Indonesia. Biological Conservation, 110, 141-152.

NG, P.K.L., TAY, J.B. \& LiM, K.K.P. (1994) Diversity and conservation of blackwater fishes in Peninsular Malaysia, particularly in the North Selangor peat swamp forest. Hydrobiologia, 285, 203-218.

Nietlisbach, P., Arora, N., Nater, A., Goossens, B., VAN SCHAIK, C.P. \& KRÚTZEN, M. (2012) Heavily male-biased long-distance dispersal of orang-utans (genus: Pongo), as revealed by Y-chromosomal and mitochondrial genetic markers. Molecular Ecology, 21, 3173-3186.

PAge, S.E. \& Rieley, J.O. (1998) Tropical peatlands: a review of their natural resource functions. with particular reference to Southeast Asia. International Peat Journal, 8, 95-106.

PAge, S.E., Rieley, J.O. \& WÜst, R. (2006) Lowland tropical peatlands of Southeast Asia. In Peatlands: Evolution and Records of Environmental and Climate Changes (eds I.P. Martini, A. Martínez Cortizas \& W. Chesworth), pp. 145-172. Elsevier, Amsterdam, The Netherlands.

Page, S.E., Siegert, F., Rieley, J.O., Boehm, H.-D.V., Jaya, A. \& Limin, S. (2002) The amount of carbon released from peat and forest fires in Indonesia during 1997. Nature, 420, 61-65.

Rijksen, H.D. \& Meijand, E. (1999) Our Vanishing Relative: The Status of Wild Orang-utans at the Close of the Twentieth Century. Kluwer Academic Publishers, Dordrecht, The Netherlands.

Sabiham, S. (2004) Ecological issues of the Mega-Rice Project in Indonesia: a case study of swampland development in Central Kalimantan. In Ecological Destruction, Health, and Development; Advancing Asian Paradigms (eds H. Furukawa, M. Nishibuchi, Y. Kono \& Y. Kaida), pp. 73-87. Kyoto University Press, Kyoto, Japan. Singleton, I., Knott, C.D., Morrogh-Bernard, H., Wich, S. \& VAN SCHAiк, C. (2009) Ranging behavior of orangutan females and social organization. In Orangutans: Geographic Variation in Behavioral Ecology and Conservation (eds S.A. Wich, S.S.Utami Atmoko, T.Mitra Setia \& C. van Schaik), pp. 205-212. Oxford University Press, Oxford, UK.

Singleton, I., Wich, S.A., Husson, S., Stephens, S., Utami-Atmoro, S.S., Leighton, M. et al. (2004) Orangutan Population and Habitat Viability Assessment: Final Report. IUCN/ SSC Conservation Breeding Specialist Group, Apple Valley, USA.

Sodhi, N.S., Koh, L.P., Brook, B.W. \& NG, P.K.L. (2004) Southeast Asian biodiversity: an impending disaster. TRENDS in Ecology \& Evolution, 19, 654-660.

Soemartono, T., Susilo, H.D., Andayani, N., Atmoko, S.S.U., Sinite, J., SAleh, C. \& Sutrisno, A. (2007) Strategi dan Rencana aksi Konservasi Orangutan Indonesia 2007-2017 (ed. Direktorat Jenderal Perlindungan Hutan dan Konservasi Alam). Departemen Kehutanan Republik Indonesia, Jakarta, Indonesia. 
Solheim, E. \& Natalegawa, R.M.M.M. (2010) Letter of intent between the Government of the Kingdom of Norway and the Government of the Republic of Indonesia on cooperation on reducing greenhouse gas emissions from deforestation and forest degradation. Oslo, Norway.

SorEnSEn, K.W. (1993) Indonesian peat swamp forests and their role as a carbon sink. Chemosphere, 27, 1065-1082.

Thomas, L., Buckland, S.T., Rexstad, E.A., LaAke, J.L., Strindberg, S., Hedley, S.L. et al. (2010) Distance software: design and analysis of distance sampling surveys for estimating population size. Journal of Applied Ecology, 47, 5-14.

Thomas, L., LaAke, J.L., Derry, J.F., Buckland, S.T., Borchers, D.L., Burnham, K.P. et al. (1998) DISTANCE v. 6.o. Research Unit for Wildlife Population Assessment, University of St Andrews, UK.

Tilman, D., May, R.M., Lehman, C.L. \& Nowak, M.A. (1994) Habitat destruction and the extinction debt. Nature, 371, 65-66.

van SChaik, C.P., Monk, K.A. \& Robertson, J.M.Y. (2001) Dramatic decline in orang-utan numbers in the Leuser Ecosystem, Northern Sumatra. Oryx, 35, 14-25.

van Schaik, C.P., Priatna, A. \& Priatna, D. (1995) Population estimates and habitat preferences of orangutans based on line transects of nests. In The Neglected Ape (eds R.D. Nadler, B.F.M. Galdikas, L.K. Sheeran \& N. Rosen), pp. 129-147. Plenum Press, New York, USA.

van Schaik, C.P. \& van Hooff, J.A.R.A.M. (1996) Toward an understanding of the orangutan's social system. In Great Ape Societies (eds W.C. McGrew, L.F. Marchant \& T. Nishida), pp. 3-15. Cambridge University Press, Cambridge, UK.

van Schaik, C.P., Wich, S.A., Utami, S.S. \& Odom, K. (2005) A simple alternative to line transects of nests for estimating orangutan densities. Primates, 46, 249-254.
Wich, S.A., Gaveau, D., Abram, N., Ancrenaz, M., Baccini, A., BREND, S. et al. (2012) Understanding the impacts of land-use policies on a threatened species: is there a future for the Bornean orang-utan? PLoS ONE, 7(11), e49142.

Wich, S.A., Meijaard, E., Marshall, A.J., Husson, S., Ancrenaz, M., Lacy, R.C. et al. (2008) Distribution and conservation status of the orang-utan (Pongo spp.) on Borneo and Sumatra: how many remain? Oryx, 42, 329-339.

Williams, N. (2007) Orang-utan extinction threat shortens. Current Biology, 17, R261.

Yule, C. (2010) Loss of biodiversity and ecosystem functioning in Indo-Malayan peat swamp forests. Biodiversity and Conservation, 19, 393-409.

\section{Biographical sketches}

Megan Cattau uses remote sensing, geospatial analysis and modelling to research the effects of human alteration of the landscape on ecosystem service provision and on the associated species drivers. She is interested in the patterns and processes of forest community change following habitat alteration in peat-swamp forest. SIMON Husson has worked on orang-utan conservation in Kalimantan since 1999, with a special focus on surveying unknown populations throughout the island, protecting populations in peat-swamp forest, and the reintroduction of ex-captive orang-utans to the wild. SUSAN CHEYNE has worked in Indonesia since 2002 and is leading a long-term study of gibbon behaviour and ecology in peat-swamp forest as well as carrying out a detailed study of felid biodiversity and conservation in the area. She has carried out surveys on flying-fox hunting and abundance and is interested in how anthropogenic factors affect biodiversity in peat-swamp forests. 